\section{Kajian Yuridis Tentang Sanksi Kebiri Dalam Sistem Pemidanaan Di Indonesia Berdasarkan Undang Undang Nomor 17 Tahun 2016 Tentang Perlindungan Anak}

Oleh :

\author{
Warsiman ${ }^{1}$ \\ Email : warsimanshmh@gmail.com
}

\begin{abstract}
Indonesia is one of signatory member of the United Nations Convention on the Rights of the Children, which requires the State to guarantee that no children may suffer torture or other cruelty, whether it is humane action or degrading treatment or punishment. Protection of children in criminal cases is categorized as special protection that requires special treatment in handling the cases.

Decency crimes generally lead to condemnation from the community; it especially comes from parents that happen to girls and boys, regarding the crime of rape, obscene acts, pedophiles and others. The arrangements that can be imposed on perpetrators prior to the existence of special laws governing pedophiles namely articles 289, 290, 292, which are regulated in the Criminal Code and articles 81, 82 and article 76D which are regulated in Law No. 16 of 2017 on the amendment of Law No. 23 of 2002 concerning children protection.

In law No. 17 of 2016 amendment to Law No. 23 of 2002 concerning child protection, it is stated in law No. 16 of 2017 enhances the sanctions for the child sexual violence perpetrators, namely by chemical castration or injection of chemical liquids and installing chips as electronic detection devices. Such actions will be punished within a maximum period of two years and it is implemented after the convict is serving a basic sentence. Perpetrators may also be subject to additional penalties in the form of announcements of the perpetrator's identity because the actions and additional penalties are excluded for the child perpetrators .
\end{abstract}

Keywords : Child, Decency Crime, Pedophile, Chemical Castration Punishment,

\footnotetext{
${ }^{1}$ Dosen Fakultas Hukum Universitas Al Azhar
}

\section{Abstrak}

Indonesia merupakan salah satu Negara anggota penandatangan dari konvensi PBB untuk Hak Anak yang mengharuskan Negara menjamin bahwa tidak ada seorang anak pun boleh mendapatkan siksaan atau kekejaman lainnya, tindakan manusiawi maupun perlakuan yag merendahkan atau hukuman. Perlindungan anak dalam perkara pidana dikategorikan sebagai perlindungan khusus yang membutuhkan perlakuan khusus dalam penanganan perkaranya.

Kejahatan terhadap kesusilaan pada umumnya menimbulkan kecaman dari masyarakat khususnya para orang tua yang terjadi terhadap anak wanita maupun pria, perihal tentang kejahatan perkosaan, perbuatan cabul, pedopil dan lainnya, pengaturan yang dapat di kenakan pada pelaku sebelum adanya undang-undang khusus yang mengatur tentang pedophil yaitu pasal 289, 290, 292, yang di atur dalam KUHP dan pasal 81,82 dan pasal 76D yang di atur dalam Undang-undang No. 16 Tahun 2017 atas perubahan Undang-undang No. 23 tahun 2002 Tentang perlindungan anak.

Undang-undang No. 17 tahun 2016 perubahan atas Undang-undang No. 23 Tahun 2002 tentang perlindungan anak, dalam Undangundang No. 16 Tahun 2017 menambah sanksi bagi pelaku kekerasan seksual anak, yaitu dengan tindakan kebiri kimia atau penyuntikan cairan kimia dan pemasangan chip sebagai alat deteksi elektronik. Tindakan tersebut akan dikenakan jangka waktu paling lama dua tahun dan dilaksanakan setelah terpidana menjalani hukuman pokok, pelaku juga dapat dikenakan pidana tambahan berupa pengumuman identitas diri si pelaku karena hukuman tindakan dan pidana tambahan ini dikecualikan untuk pelaku anak.

Kata Kunci : Anak, kejahatan kesusilaan, pedopil, hukuman kebiri kimia,

\section{Pendahuluan}

\section{A. Latar Belakang}


Media Komunikasi dan Informasi Hukum dan Masyarakat

Sebagaimana diketahui bahwa kasus tindak kekerasan seksual saat ini sangat banyak dimasyarakat yaitu tindak kekerasan seksual terhadap anak. Tindak kekerasan ini dipicu dari berbagai hal, seperti beredarnya foto dan video porno yang beredar di masyarakat luas maupun film-film yang tidak layak di tonton oleh anak yang berusia di bawah 18 (delapan belas tahun). Terdapat beberapa faktor yang mempengaruhi yaitu faktor lingkungan, pergaulan, minum-minuman keras yang beralkohol dan lain sebagainya. Tindak kekerasan seksual seperti pemerkosaan yang berakhir pembunuhan sekarang ini banyak terjadi di lingkungan masyarakat.

Tindak kekerasan seksual terjadi bukan hanya kesalahan dari pelakunya saja tetapi korban juga bisa menjadi pemicu dari tindak pelaku kejahatan. Saat ini banyak wanita berpakaian yang tidak sesuai dengan aturan, norma dan agama, mereka dengan bangga dan mudahnya memancing kejahatan dengan menggunakan pakaian yang kurang pantas, mempertontonkan aurat, berpakaian ketat dan sebagainya yang menurut norma dan agama terutama agama Islam pakaian tersebut tidak selayaknya di gunakan agar tidak menjadi korban kejahatan. Kekerasan seksual terjadi bukan hanya kepada orang dewasa saja, bahkan banyak terjadi kekerasan atau tindakan perkosaan terhadap anak yang dibawah umur. Kekerasan seksual terhadap anak biasanya pelakunya adalah orang dewasa yang lingkungannya dekat dengan korban, baik itu lingkungan keluarga maupun orang-orang dilingkungan dekat dengan anak tinggal, pelaku dalam kasus ini sering di sebut dengan pedophilia.

Pedophilia dapat diartikan pula dengan kecendrungan seseorang yang telah dewasa baik pria maupun wanita untuk melakukan aktivitas seksual berupa hasrat ataupun fantasi implus seksual dengan anak-anak dibawah umur. Penderita pedophilia juga bisa tertarik hanya pada anak-anak yang masih mempunyai hubungan darah/keluarga dari penderita (incest) karateristik yang dimiliki oleh penderita pedophilia.

Tindak pidana pencabulan di Indonesia saat ini mengalami darurat kekerasan seksual terhadap anak yang amat sangat menghawatirkan di kalangan masyarakat khususnya di lingkungan anak di bawah umur. Peraktek kejahatan terhadap anak termasuk ekshibitionisme (dorongan fantasi seksual yang mendesak dan terus-menerus) terhadap anak dan manipulasi terhadap anak-anak. Dengan kata lain, penjatuhan pidana terhadap kejahatan pedophilia tentu belum seimbang dengan dampak yang di timbulkannya yakni korban yang masih anak-anak tentu akan mengalami trauma yang berkepanjangan hingga dewasa bahkan bisa sampai seumur hidupnya.

Pengaturan tindak pidana terhadap kejahatan pedophilia memang tidak di atur khusus dalam peraturan perundang-undangan di Indonesia. Selama ini untuk menjerat pelaku salah satunya adalah menggunakan ketentuan yang ada dalam KUHP yaitu Pasal 290, Pasal 292 dan Pasal 287 dalam BAB XIV tentang Kejahatan Terhadap Kesusilaan.

Upaya pembaharuan hukum pidana dalam hal kasus tindak pidana pedophilia ini adalah dengan memberikan hukuman kebiri sebagai upaya hukum untuk memberikan efek jera bagi pelaku. Kebiri disebut juga pengkebirian atau kastrasi yaitu tindakan bedah atau kimia yang bertujuan menghilangkan fungsi testis pada jantan atau fungsi ovarium pada 
Media Komunikasi dan Informasi Hukum dan Masyarakat

betina, pengebirian dapat dilakukan baik pada hewan maupun manusia. Kebiri secara fisik adalah memotong saluran testis makhluk hidup (hewan, manusia) sehingga tidak lagi menghasilkan sperma.

Kebiri kimiawi adalah pengebirian dengan cara menyuntik seseorang pria dengan obat-obatan yang secara efektif menyebabkan tumpulnya atau hilangnya gairah seksualnya untuk jangka waktu tertentu. Hukum kebiri ini menjadi alasan sebagai upaya hukum baru terhadap pelaku tindak pidana pedophilia, karena di Indonesia kejahatan seksual terhadap anak akhir-akhir ini telah begitu meluas dan menunjukkan peningkatan yang sangat signifikan.

Selain itu, hukum yang telah ada dan diterapkan untuk menjerat pelaku tindak pidana pedophilia ini dirasa belum memberikan keadilan bagi korban, korban yang notabane adalah anak-anak yang seharusnya mendapat perlindungan justru mendapat perlakuan yang bisa memberikan dampak traumatis secara psikologis yang berkepanjangan sampai seumur hidupnya dan kehilangan masa depannya akibat terauma tersebut. Bukan tidak jarang korban setelah dewasa bisa menjadi pelaku tindak pidana pedophilia juga akibat dari trauma psikologis yang mendalam, bahkan akan terus terbayang dalam ingatan mereka ketika aksi pelaku dilakukan dengan kekerasan sehingga akan memunculkan sifat dendam yang sulit dihilangkan. Akibat sifat dendam tersebut bisa memungkinkan iapun akan menjadi pelaku pedophilia karena semasa kecilnya pernah menjadi korban kejahatan pedophilia.

\section{B. Perumusan Masalah}

Berdasarkan latar belakang yang telah dijelaskan, maka dapat dirumuskan permasalahan sebagai berikut :

1. Bagaimanakah pengaturan sanksi kebiri terhadap kejahatan pedophilia di Indonesia?

2. Bagaimanakah penerapan sanksi kebiri terhadap pelaku kejahatan pedophilia di Indonesia?

3. Bagaimanakah kendala dalam penerapan sanksi kebiri terhadap tindak pidana kejahatan pedophilia di Indonesia?

\section{Metode Penelitian}

Metode penelitian yang dipergunakan untuk menjawab permasalahan yang adalah bersifat deksriptif analitis yaitu penelitian yang berusaha untuk menggambarkan dan menguraikan tentang pemasalahan yang berkaitan dengan sanksi kebiri dalam sistem pemidanaan di Indonesia. Dilihat dari segi pendekatan penelitiannya, maka penelitian ini menggunakan pendekatan yuridis normatif dan pendekatan yuridis empiris. Pendekatan yuridis normatif dimaksudkan sebagai penelaahan dalam tataran konseptional tentang arti dan maksud berbagai peraturan hukum nasional yang berkaitan dengan perlindungan anak berdasarkan agama, hak asasi manusia maupun perundang-undangan yang berlaku di Indonesia sedangkan pendekatan yuridis empiris adalah penelitian ini bertitik tolak dari pemasalahan dengan melihat kenyataan yang terjadi di lapangan, kemudian menghubungkannya dengan peraturan perundang-undangan yang berlaku. 
Media Komunikasi dan Informasi Hukum dan Masyarakat

\section{Hasil dan Pembahasan}

\section{A. Pengaturan Sanksi Kebiri Terhadap Kejahatan Pedophilia Di Indonesia.}

Lahirnya Undang-Undang Perlindungan Anak, berawal dari salah satu bentuk keseriusan pemerintah meratifikasi Konvensi Hak Anak (KHA) tahun 1990. Rancangan Undang-Undang Perlindungan Hak Anak ini telah diusulkan sejak tahun 1998. Namun ketika itu, kondisi perpolitikan dalam negeri belum stabil sehingga RUU Perlindungan Anak, dibahas pemerintah dan DPR, pertengahan tahun 2001. Pasal-pasal serta ayat yang memenuhi Undang-Undang ini terbaca bahwa bangsa ini bertekat untuk melindungi anak-anak. Hukuman fisik bagi anak-anak, meliputi dilema sanksi hukuman fisik ${ }^{2}$, yang kemudian dilarang oleh UndangUndang RI No.23 tahun 2002.

Pengaturan sanksi yang diberlakukan menurut konvensi PBB untuk hak anak menyatakan Negara menjamin bahwa "Tidak ada seorang anakpun boleh mendapatkan siksaan atau kekejaman lainnya, tindakan manusiawi maupun perlakuan yang merendahkan atau hukuman". Berkenaan dengan Perlindungan anak dalam perkara pidana bahwa Indonesia menetapkan sebagai perlindungan khusus yang membutuhkan perlakuan khusus dalam penanganan perkaranya. $^{3}$

${ }^{2}$ W. Mulyanah, Hukum dan Hak-hak Anak, CV. Rajawali, Jakarta, 1986, hal.254

3In'am Sulaiman, Masa Depan Pesantren (Eksistensi Pesantren di Tengah Gelombang Modernisasi). Madani (Kelompok Intrans Publishing, Malang, 2010, hal.341. Lihat juga Moleong, lexi j, Metodologi Penelitian Kualitatif (edisi revisi). PT Remaja Rosdakarya, Bandung, 2006, hal. 78. Bandingkan Ritzer, George, dan Douglas, Goodman, Teori Sosiologi Dari Teori Sosiologi Klasik Sampai Perkembangan Mutakhir Teori Sosial Postmodern. Kreasi Wacana, Yogyakarta, 2008, hal. 18. Tidak seorangpun menginginkan terjadinya tindak kekerasan, apalagi di lembaga pendidikan yang sepatutnya menyelesaikan masalah secara damai dan edukatif. Namun kenyataannya masih banyak yang melakukan kekerasan
Dalam undang-undang terakhir, anakanak berusia di bawah 18 tahun mendapat perlindungan dari berbagai bentuk eksplotasi dan kekerasan. Jangankan penganiaya anak sendiri, orang yang menelantarkan anak orang lain sehingga menjadi sakit atau menderita pun bisa di penjara lima tahun. Hanya prakteknya tidak gampang memperkarakan orang tua yang melakukan kekerasan fisik terhadap anaknya. Anak yang jadi korban penganiayaan atau kekerasan seksual biasanya belum mampu atau tidak berani melapor ke polisi. Akibatnya banyak kasus yang baru terungkap setelah anak meninggal dunia. Perlakuan salah terhadap anak, dibagi menjadi dua golongan besar yaitu berasal dari dalam keluarga dan berasal dari luar lingkungan keluarga.

1. Dalam keluarga, berupa :

a. Penganiayaan fisik berupa cacat fisik sebagai akibat hukuman badan di luar batas, kekejaman atau pemberian racun.

b. Kelalaian merupakan perbuatan yang tidak disegaja akibat ketidaktahuan atau akibat kesulitan ekonomi, meliputi pemeliharaan yang kurang memadai, yang dapat mengakibatkan gagal tumbuh, anak merasa kehilngan kasih sayang, ganguan kejiwaan, kelalaian dalam mendapatkan pengobatan, misalnya tidak mendapat imunisasi, dan lalai dalam mendidik anak untuk mampu berinteraksi dengan lingkungannya, gagal menyekolahkannya atau menyuruh anak mencari nafkah untuk keluarga sehingga anak terpaksa putus sekolah.

terhadap anak. merupakan salah satu penanda tanganan dari konversi PBB untuk Hak-hak Anak, yang mengharuskan negara menjamin bahwa: "Tak seorang anakpun boleh mendapatkan siksaan atau kekejaman lainnya, tindakan tidak manusiawi ataupun perlakuan yang merendahkan atau hukuman". Meski demikian, tampaknya undang-undang tersebut belum dipahami oleh kebanyakan pelaku. 
Media Komunikasi dan Informasi Hukum dan Masyarakat

c. Penganiayaan emosional berupa kecaman dengan kata-kata yang merendahkan anak, atau tidak mengakui anak. Sering pula berlanjut pada melalaikan anak, mengisolasinya dari lingkungan, atau menyalahkan anak secara terus menerus. Biasanya diiringi pula dengan penganiayaan dalam bentuk lain.

2. Di luar keluarga berupa :

Perilaku yang salah terhadap anak itu bukan hanya terjadi dalam keluarga saja melainkan dari luar keluarga, misalnya lingkungan, pergaulan, teman, yang akhirnya menimbulkan permasalahan bagi anak, baik anak sebagai korban atau pelaku kejahatan itu sendiri, menurut data dari dinas sosial tahun 2009 menunjukkan bahwa :
a. $47 \%$ menyatakan bahwa remaja sering melakukan tawuran dan kekerasan.
b. $59 \%$ menyatakan bahwa remaja mengkonsumsi minuman keras.
c. $28 \%$ menyatakan bahwa remaja menggunakan obat terlarang.
d. $74 \%$ menyatakan bahwa remaja melakukan hubungan seks.

Perilaku menyimpang para remaja seperti seks menyatakan bahwa :
a. $93,7 \%$ remaja pernah melakukan ciuman, petting, dan oral seks.
b. $62,7 \%$ remaja SMP tidak perawan.
c. $21,2 \%$ remaja SMU pernah Aborsi.
d. $97 \%$ pernah melihat film porno.

Berdasarkan data di atas maka anak harus perlu di lindungi dari berbagai pihak termasuk keluarga, sebagai salah satu contoh kasus pedophil yang terjadi pada tahun 2016 yaitu, kasus kekerasan seksual terhadap MK, AL, dan DA, siswa Jakarta Internasional School (JIS) menetapkan dua guru TK JIS sebagai tersangka, dua guru itu adalah Neil Bantleman dan Ferdinant Michael atau Ferdinant Tjiong. Penetapan kasus hukuman mereka dilakukan setelah penyidik unit perlindungan perempuan dan anak (PPA) Polda Metro Jaya gelar perkara, Neil Bantleman adalah staf JIS yang berasal dari kanada, sedangkan Ferdinant Michael merupakan warga negara Indonesia yang menjabat sebagai asisten guru di JIS tersebut.

Keduanya dijerat dengan pasal 81 dan 82 Undang-undang Nomor 23 Tahun 2002 Tentang perlindungan Anak dengan ancaman maksimal 15 tahun penjara dan dengan denda minimal 60 juta Rupiah dan maksimal 300 juta Rupiah. Pernah juga terjadi kejadian yang sama namun tempat yang berbeda, kasus ini sempat surut dari pandangan media saat di Sukabumi polisi menangkap pria bernama Andri Sobari alias Emon (24) yang telah menyodomi anak di bawah umur. Kasus Emon terungkap berawal dari puluhan anak laki-laki berusia 14 tahun bersama orang tua dari anak-anak tersebut mendatangi dan melaporkan tersangka ke unit perlindungan perempuan dan anak (PPA) Polres Sukabumi Kota karena telah menjadi tindak kekerasan seksual.

Anak yang rata-rata masih duduk di bangku Sekolah Dasar (SD) ini menjadi korban pelecehan seksual yang dilakukan oleh Emon. Emon ditetapkkan sebagai tersangka, pelaku dijerat dengan pasal 82 tentang perlindungan anak jo pasal 292 KUHP tentang pencabulan, dan pasal 64 KUHP tentang perbuatan berlanjut pada persidangan pertama selasa 26 desember 2016 berdasarkan fakta dan keterangan para saksi Emon dikira sah dan meyakinkan telah melakukan tindakan tidak bermoral kepada puluhan anak yakni melecehkan dan menyodomi anak di bawah umur, Majelis hakim pengadilan negeri Sukabumi menetapkan pelaku telah melanggar pasal $289,290,292$, ini di ataur dalam KUHP, dan pasal 81, 82 di atur dalam Undang Undang Nomor 23 tahun 2002 tentang perlindungan anak. 
Media Komunikasi dan Informasi Hukum dan Masyarakat

Pasal-pasal tersebut nyatanya tidak memberikan efek jera bagi pelaku tindak pidana pedophilia, hal ini dibuktikan dengan semakin banyak dan maraknya kasus kekerasan/plecehan seksual terhadap anak, hukum yang berlaku dari tahun ke tahun tidak mengalami perubahan. Hal ini merupakan kelemahan hukum yang ada karena hukum yang harusnya bisa memberikan efek jera bagi pelaku dan perlindungan dan pencegahan bagi korban tidak lagi berlaku dan berfungsi sebagaimana mestinya.

\section{B. Penerapan sanksi kebiri terhadap pelaku kejahatan pedophilia di Indonesia}

Seringnya terjadi kasus kekerasan, terutama kekerasan terhadap anak maka Komisi Nasional Perlindungan Anak (Komnas PA) mendapat laporan sebanyak 2.737 kasus kekerasan terhadap anak di Tahun 2017. Ketua Komisi Nasional Perlindungan Anak yaitu Aris Merdeka Sirait menyebut sebagian besar dari kasus yang di laporkan yaitu 52\% (1.424 kasus) merupakan kekerasan seksual terhadap anak. Dari 2.737 kasus yang dilaporkan menghasilkan 2.848 korban yang 52\% di antaranya merupakan kekerasan seksual disusul kekerasan fisik sebanyak 30\% (825 kasus), kekerasan pisikis 17\%, (447kasus), kekerasan bentuk lain sebanyak 11 kasus atau $1 \%$. Aris Merdeka Sirait menyatakan bahwa dari 1.424 kasus kekerasan seksual yang terjadi kasus sodomi menjadi kasus yang terbanyak yaitu 771 kasus (54\%), pencabulan sebanyak 551 kasus ( $36 \%$ ), perkosaan sebanyak 122 kasus $(9 \%)$, dan incest sebanyak 20 kasus (1\%).

Dari 2.848 korban kekerasan anak, sebagian besar merupakan anak laki-laki yaitu 1.698 korban (59\%), perempuan sebanyak
1.131 anak (40\%), dan tidak di ketaui yakni masih berupa janin sebanyak 19 anak (1\%). Dari segi usia 110 Anak berada di rentang usia 0-5 Tahun (4\%), 1.629 anak pada usaia 6-12 tahun $(57 \%)$, serta 1.109 anak pada rentang usia 13-18 tahun (39\%), secara strata ekonomi, anak kelasmenengaj menjadi korban palingbnyak yaitu 1.805 anak (63\%), kalangan bawah sebanyak 712 anak (25\%), dan anak kalangan atas sebanyak 41 anak (1\%).

Sebagai contoh kasus pedophil yang telah terjadi yaitu, kasus kekerasan seksual terhadap MK, AL, dan DA, siswa Jakarta Internasional School (JIS). Pengadilan Negeri Jakarta Selatan telah menetapkan dua guru TK JIS sebagai tersangka, dua guru itu adalah Neil Bantleman dan Ferdinant Michael atau Ferdinant Tjiong. Keduanya dijerat dengan pasal 81 dan 82 Undang-undang Nomor 23 Tahun 2002 tentang Perlindungan Anak dengan ancaman maksimal 15 tahun penjara dan dengan denda minimal 60 juta Rupiah dan maksimal 300 juta Rupiah

Contoh lain seperti terungkap seorang pria bernama Andri Sobari alias Emon (24) telah menyodomi anak di bawah umur. Emon ditetapkkan sebagai tersangka, pelaku dijerat dengan pasal 82 tentang perlindungan anak junto pasal 292 KUHP tentang pencabulan, dan pasal 64 KUHP tentang perbuatan berlanjut pada persidangan pertama selasa 26 desember 2016 berdasarkan fakta dan keterangan para saksi Emon dikira sah dan meyakinkan telah melakukan tindakan tidak bermoral kepada puluhan anak yakni melecehkan dan menyodomi anak di bawah umur, Majelis hakim Pengadilan Negeri Sukabumi yang diketahui Wahyu Prasetio bersama Widia Sari Kuncoro menjatuhkan hukuman 17 tahun penjara. 
Media Komunikasi dan Informasi Hukum dan Masyarakat

Setelah banyaknya kejadian kejahatan terhadap anak maka presiden mengeluarkan PERPU No, 1 Tahun 2016 yang sekarang menjadi Undang Undang No. 17 Tahun 2016, dimana jika kejadiannya sebelum pengesahan Undang Undang kebiri ini hanya dikenakan dengan Undang Undang biasa dan belum memberikan efek jera bagi pelaku, setelah keluarnya Undang Undang No. 17 Tahun 2016, penerapan sanksi kebiri terhadap para pelaku kejahatan pedopilia di Indonesia berdasarkan Undang Undang No. 17 Tahun 2016 tentang perlindungan Anak yaitu pasal 81 dan pasal 82 yang di mana inti dari pasal ini yaitu terhadap pelaku tindak pidana pedopilia akan di kenakan sanksi kebiri kimia, dan pemasangan alat pendeteksi elektronik. Walaupun banyak kecaman dari masyarakat yang memnyatakan bahwa penyuntikan zat kimia atau kebiri sangat bertentangan dengan HAM, di mana negara harus menjunjung tinggi HAM tersebut.

Deputi Bidang Perlindungan Perempuan dan Anak Kementrian Koordinator Bidang pembangunan manusia dan Kebudayaan RI, Sujatmiko, memberikan penjelasan terkait polemik yang timbul di masyarakat mengenai sanksi kebiri ini. Terdapat beberapa hal yang harus diketahui oleh masyarakat mengenai hukum kebiri, Sujatmiko mengatakan bahwa Undang-undang ini akan di terapkan dengan tetap memperhatikan koridor hukum, termasuk penghormatan terhadap HAM, baik pelaku maupun korban yang merupakan kelompok rentan, beliau juga mengatakan hukum kebiri akan diberikan melaui suntikan dibarengi dengan proses rehabilitasi. Proses rehabilitasi tersebut untuk menjangkau pelaku tidak mengalami efek negatif lain selain penurunan libido. ${ }^{4}$

Suntikan kimia ini sifatnya tidak permanen efek suntikan ini hanya muncul setelah tiga bulan. Oleh karena itu suntikan kimia akan di berikan secara berkala pada pelaku melalui pengawasan ketat oleh ahli jiwa dan kesehatan. Pengawasan terhadap pelaku tindak kejahatan pedophil ini berguna untuk memonitor pelaku jangan sampai pelaku mengalami dampak negatif lain selain penurunan saraf libido.

\section{Kendala Dalam Penerapan Sanksi Kebiri Terhadap Tindak Kejahatan Pedophilia Di Indonesia}

Upaya mewujudkan masyarakat Indonesia yang sejahtera, adil dan makmur yang merata baik materil dan spiritual berdasarkan Pancasila dan Undang Undang Dasar Negara Republik Indonesia Tahun 1945, Presiden Republik Indonesia dengan tegas menyatakan dan mendukung pemberian sanksi kebiri bagi pelaku pencabulan terhadap anak di bawah umur, karena efek yang di timbulkan bila di biarkan secara bekerlanjutan dapat berdampak semakin buruk. Dalam hal ini dapat berefek buruk bagi generasi muda bangsa Indonesia.

Anak adalah masa depan kita dan anak adalah penerus bangsa, dalam hal ini hukuman pengebirian syaraf libido sedikit mendapat pertentangan oleh beberapa pihak dengan menjujung HAM (Hak Asasi Manusia), karena ciri-ciri yang harus melekat pada negara hukum adalah adanya pengakuan dan perlindungan HAM, peradilan yang bebas dan kepastian hukum.

4 www.kompas.com penerapan saksi kebiri di Indonesia 
Media Komunikasi dan Informasi Hukum dan Masyarakat

Hukuman pengebirian syaraf libido bagi terpidana pencabulan pada dasarnya adalah perlindungan HAM bagi orang banyak karena kasus pencabulan terhadap anak di bawah umur merupakan salah satu extraordinary crime, anak-anak adalah harta terbesar keluarga dan harapan penerus bangsa. Peradilan di Indonesia memang sudah bersifat tegas, itulah salah satu respons masyarakat terhadap keputusan Presiden Republik Indonesia yang menandatangani Peraturan Pemerintah Pengganti Undang-Undang Nomor 1 Tahun 2016 yang sekarang telah menjadi Undangundang Nomor 17 tahun 2016 tentang perubahan kedua Undang-undang Nomor 23 Tahun 2002 tentang Perlindungan Anak. Perpu ini memperberat sanksi bagi pelaku kejahatan pencabulan, yakni hukuman mati, penjara seumur hidup, maksimal 20 tahun penjara dan minimal 10 tahun penjara. Undang-undang ini juga mengatur tiga sanksi tambahan, yakni kebiri kimiawi, pengumuman identitas ke publik, serta pemasangan alat deteksi elektronik atau pemasangan chip.

Melihat sanksi yang di berikan kepada pelaku maka pemerintah tidak main-main dalam memerangi tindak pidana pencabulan. Disesuaikan dengan kategori atau beratnya kejahatan yang dilakukan kejahatan asusila yang menyebabkan meninggalnya korban dan dapat merusak sendi-sendi kehidupan maka dari itu hukuman berupa pengebirian kimiawi diperlukan sebagai sanksi yang berat bagi para pelaku. Hukuman kebiri mendapatkan legalitasnya dari Pasal $28 \mathrm{~J}$ ayat (2) UndangUndang Dasar 1945 yaitu dalam menjalankan hak dan kebebasannya, setiap orang wajib tunduk kepada pembatasan yang ditetapkan dengan undang-undang dengan maksud semata-mata untuk menjamin pengakuan serta penghormatan atas hak dan kebebasan orang lain dan untuk memenuhi tuntutan yang adil sesuai dengan pertimbangan moral, nilai-nilai agama, keamanan, dan ketertiban umum dalam suatu masyarakat demokratis.

Hakim yang secara khusus menjadi aktor utama dalam menjalankan aktivitas peradilan untuk memeriksa, mangadili, dan memutus suatu perkara yang diajukan. Segala campur tangan dalam urusan peradilan oleh pihak lain di luar kekuasaan kehakiman dilarang, kecuali dalam hal sebagaimana dimaksud dalam Undang-Undang Dasar Republik Indonesia Tahun 1945. Dengan demikian hakim dapat memberi keputusan yang sesuai dengan hukum dan rasa keadilan masyarakat. Meskipun pada asasnya hakim itu mandiri atau bebas, tetapi kebebasan hakim itu tidaklah mutlak, karena dalam menjalankan tugasnya hakim dibatasi oleh Pancasila, Undang-undang dasar, peraturan perundangundangan, ketertiban umum dan kesusilaan. Itu adalah faktor-faktor yang dapat membatasi kebebasan hakim, Menurut ketentuan Pasal 8 ayat (2) Undang-Undang Nomor 48 Tahun 2009 tentang kekuasaan kehakiman ditentukan bahwa dalam mempertimbangkan berat ringannya pidana, hakim wajib memperhatikan pula sifat yang baik dan jahat dari terdakwa.

Berdasarkan ketentuan tersebut, dalam menentukan berat ringannya pidana yang akan dijatuhkan, hakim wajib memperhatikan sifat baik atau sifat jahat dari terdakwa sehingga putusan yang dijatuhkan sesuai dan adil dengan kesalahan yang dilakukannya. Menurut Pasal 183 Undang-Undang Nomor 8 Tahun 1981 tentang Hukum Acara Pidana (KUHAP) ditentukan bahwa hakim tidak boleh menjatuhkan pidana kepada seseorang kecuali apabila dengan sekurang-kurangnya dua alat 
Media Komunikasi dan Informasi Hukum dan Masyarakat

bukti yang sah ia memperoleh keyakinan bahwa suatu tindak pidana benar-benar terjadi dan bahwa terdakwalah yang bersalah melakukannya.

\section{Penutup}

\section{A. Kesimpulan}

Berdasarkan uraian-uraian yang telah dikemukakan terdahulu, maka diambillah beberapa kesimpulan-kesimpulan sebagai berikut:

1. Tingkat kejahatan kesusilaan di Indonesia semakin meningkat, khususnya yang dialami oleh anak. Pengaturan sanksi yang diberlakukan menurut konvensi PBB untuk hak anak menyatakan Negara menjamin bahwa tidak ada seorang anakpun boleh mendapatkan siksaan atau kekejaman lainnya, tindakan manusiawi maupun perlakuan yang merendahkan atau hukuman. Berkenaan dengan Perlindungan anak dalam perkara pidana bahwa Indonesia menetapkan sebagai perlindungan khusus yang membutuhkan perlakuan khusus dalam penanganan perkaranya.

2. Perkembangan pengaturan sanksi terhadap kejahatan kesusilaan seperti perkosaan, perbuatan cabul,, pedophil dan lainnya diatur dalam Kitab Undang Undang Hukum Pidana (KUHP) pasal 289, 290, 292 kemudian dalam Undang Undang Nomor 16 Tahun 2017 atas perubahan Undang Undang Nomor 23 Tahun 2002 tentang perlindungan anak pada pasal 81, 82 dan $76 \mathrm{D}$.

3. Sesuai dengan amanat konvensi Perserikatan Bangsa Bangsa (PBB) untuk hak anak, maka perlindungan terhadap anak yang mengalami tindak kekerasan seksual yang dilakukan orang dewasa di Indonesia, sanksi atau hukuman yang diberikan terhadap para pelaku pedophil atau kekerasan seksual anak mengalami perubahan berupa tindakan kebiri kimia atau penyuntikan cairan kimia dan pemasangan chip sebagai alat deteksi elektronik. Penambahan sanksi ini diatur dalam Undang Undang Nomor 17 Tahun 2016 perubahan atas Undang Undang Nomor 23 Tahun 2002.

\section{B. Saran}

Setelah penulis memaparkan kesimpulan hasil penelitian diatas, maka berikut ini sebagai bahan masukan bagi pembuat Undang Undang maupun para pembuat kebijakan untuk menyempurnakan aturan yang akan diberlakukan dimasa yang akan datang, berikut ini penulis memberikan / menguraikan beberapa saran-saran :

1. Diperlukan komitmen dari segenap jajaran pemangku kebijakan khususnya dari badan legislatif untuk lebih progresif membuat aturan aturan yang dapat mengurangi angka kejahatan seksual terhadap anak dalam mendukung amanat yang telah ditetapkan dalam konvensi Perserikatan Bangsa Bangsa (PBB) tentang hak anak.

2. Aturan yang telah ada nyatanya belum memberikan efek jera terhadap para pelaku kejahatan pedophil, hal ini di buktikan dengan terus adanya tindak kejahatan terhadap anak, yang dimana aturan yang dibuat belum menimbulkan perubahan yang siknifikan terhadap tindak kejahatan terutama kejahatan pedophil, dan seharusnya pemerintah mengkaji ulang tentang hukuman yang layak di berikan, agar memberikan efek jera bagi pelaku agar 
Media Komunikasi dan Informasi Hukum dan Masyarakat

tidak terulang kasus yang sama terhadap kekerasan seksual terhadap anak.

3. Pemerintah harus berhati-hati dalam mengambil keputusan untuk menerapkan sanksi kebiri kepada pelaku pedophil, perlu adanya kajian lebih dalam mengenai sanksi kebiri apakah penyuntikan cairan kimiawi bisa di terapkan atau tidak, selain itu untuk melaksanakan atau mengeksekusi para pelaku tindak pidana pedophil harus dilengkapi peralatan dan fasilitas yang memadai, pemerintah juga harus mengeluarkan Peraturan Pemerintah untuk bagaimana cara pelaksanaan kebiri tersebut, karena sampai saat ini juga belum ada peraturan mengenai proses pelaksanaan kebiri tersebut.

\section{Daftar Pustaka}

\section{A. Buku}

Ashshiddiqi T.M. Hasbi, dkk, Al-quran dan terjemahannya, Khadim al haramainasy syasifain (pelayan ke dua tanah suci).

Djamali Abdoel,Pengaturan IImu Hukum, Raja Grafindo Persada, Jakarta, 2007.

Ritzer, George, dan Douglas, Goodman, Teori Sosiologi Dari Teori Sosiologi Klasik Sampai Perkembangan Mutakhir Teori Sosial Postmodern. Kreasi Wacana, Yogyakarta, 2008.

In'am Sulaiman , Masa Depan Pesantren (Eksistensi Pesantren di Tengah Gelombang Modernisasi). Madani (Kelompok Intrans Publishing, Malang, 2010.

Lexi J.Moleong, Metodologi Penelitian Kualitatif (edisi revisi). PT Remaja Rosdakarya, Bandung, 2006.

Wadong Maulana Hasan, Pengaturan Advokasi Dan Hukum Perlindungan Anak, PT.Gramedia Widiasarana Indonesia, Jakarta, 2000.
Wijaya Andika, Darurat Kejahatan Seksual, cetakan pertama, Sinar Grafika, Jakarta Timur, 2016.

W. Mulyanah, Hukum dan Hak-hak Anak, CV. Rajawali, Jakarta, 1986.

\section{B. Undang-Undang}

Undang-Undang Dasar 1945, Surabaya, Triana Media

Undang-undang Nomor 23 tahun 2003 tentang Perlindungan Anak

Kitap Undang-undang Hukum Pidana, Acara Pidana, Bandung, Citra Umbara, 2008

Undang-Undang Repoblik Indonesia Nomor 39 Tahun 1999 Tentang Hak Asasi Manusia

Undang-Undang Repoblik Indonesia Nomor 13 Tahun 2003 tentang ketenagakerjaan.

Undang-undang Repoblik Indonesia Nomor 23 Tahun 2002 tentang perlindungan anak, sebagaimana telah diubah dengan Undang-Undang Repoblik Indonesia Nomor 17 Tahun 2016 tentang perubahan atas Undang-Undang Nomor 23 Tahun 2002 Tentang Perlindungan Anak.

Keputusan presiden Nomor 36 Tahun 1990 tentang pengesahan convention on the rights of the child ( konvensi tentang Hak Anak).

Surat keputusan Menteri Sosial RI Nomor 81/huk/1997 tentang Pembentukan Lembaga Perlindungan Anak 


\section{Peran Genre Narkotika Di Sma Negeri 1 Kualuh Selatan Dalam Pencegahan Pemberantasan Penyalahgunaan Dan Peredaran Gelap Narkotika (P4GN) Di Labuhanbatu Utara}

$$
\text { oleh: }
$$

Indra Kumalasari $\mathbf{M}^{\mathbf{5}}$

Email: Indrakumalasarim@gmail.com

\begin{abstract}
Abstrak
Adanya temuan bagi siswa yang menggunakan Narkotika berawal dari coba-coba, hal ini sangat berpengaruh pada prilaku siswa itu sendiri. hal ini terjadi dikarenakan kurang aktifnya peran dari GenRe Narkotika dalam implementasi dari program pencegahan pemberantasan penyalahgunaan dan peredaran gelap narkotika (P4GN) di Kabupaten Labuhanbatu Utara. Tujuan dari Penelitian ini adalah untuk mengetahui peran dari GenRe narkotika yang sudah dibentuk di SMA Negeri 1 Kualuh selatan dalam upaya pencegahan peredaran gelap narkotika dikalangan siswa.
\end{abstract}

Hasil penelitian ini yaitu SMA Negeri 1 Kualuh Selatan telah membentuk GenRe Narkotika sebagai upaya dalam pencegahan peredaran gelap narkotika sebagaimana amanah dari undang-undang no 35 tahun 2009 tentang narkotika. Akan tetapi GenRe narkotika yang sudah dibentuk ini belum efektif sebagaimana perannya dikarenakan hanya aktif pada ajang kopetisi peran GenRe narkotika pada tingkat provinsi. Pengetahuan tentang bahaya narkotika yang mempunyai sanksi hukum bagi pengedar dan pengguna masih belum baik dalam penguasaan dasar materi. Diharapkan pada pihak sekolah untuk lebih memberikan pengetahuan materi lebih baik lagi dan pihak sekolah lebih aktif lagi melibatkan akademisi dalam hal ini pihak yang mempunyai peran utama diantaranya penegak hukum, pemerintah daerah ataupun BNNK Labuhanbatu utara Dan bagi pemerintah daerah lebih aktif dan mensuport GenRe Narkotika yang sudah ada

\footnotetext{
${ }^{5}$ Dosen Fakultas Hukum, Universitas Labuhanbatu
}

seperti halnya Ddi SMA Negeri 1 Kualuh Selatan Labuhanbatu Utara.

Kata kunci: Peran GenRe Narkotika dalam Pencegahan dan Pemberantasan.

\section{Abstract}

The findings about the students who use narcotics are originated from trial and error. It is very influential on the behavior of the students themselves. This happens due to the inactivity of the role of narcotics genre in the implementation of the prevention program to eradicate abuse and illicit drug trafficking in North Labuhanbatu Regency. The purpose of this study was to determine the role of the narcotics genre that had been formed at SMA Negeri 1 South Kualuh in order to prevent illicit drug trafficking among students.

The results of this study showed that the students of SMAN 1 South Kualuh has established the Narcotics Genre as an effort in the prevention of illicit trafficking of narcotics as well as the mandate of law No. 35 of 2009 on narcotics. However, the narcotics genre that has been formed has not been as effective as its role because it is only active at the provincial level competition for the role of narcotics genre. Knowledge about the danger of narcotics that have legal sanctions for the dealers and users is still not good in mastering the basic material. It is expected that the school will provide better material knowledge about the danger of narcotics and the school is more active in involving academics in this case those who have the main role include law enforcement, local government or North Labuhanbatu BNNK. Moreover, it is suggested for the local governments to be more active and to support the Narcotics Genre which already exists as well as at SMA Negeri 1 South Kualuh in North Labuhanbatu.

Keywords: Narcotics GenRe Role in Prevention and Eradication 
Media Komunikasi dan Informasi Hukum dan Masyarakat

\section{PENDAHULUAN}

\section{A. Latar Belakang Masalah}

Indonesia adalah negara yang mempunyai wilayah yang sangat luas dengan jumlah penduduk yang cukup padat terkhusus diwilayah perkotaan. Terlepas dari semua itu semakin banyak jumlah penduduk samakin rentan akan tindak pidana kejahatan dikarenakan salah satu faktor utama adalah minimnya lapangan pekerjaan dan masih rendahnya sumber daya manusianya yang ada. Faktor Ekonomi merupakan salah satu penyebab seseorang melakukan tindak pidana. Kejahatan yaitu perilaku yang merugikan atau perilaku yang bertentangan dengan ikatanikatan sosial (anti sosial) atau perilaku yang tidak sesuai dengan pedoman masyarakat ${ }^{6}$. Kejahatan merupakan prilaku sosial yang melanggar ketentuan peraturan perundangundangan yang sifatnya megatur tata tertib yang bertujuan untuk kepentingan umum. Semakin banyaknya prilaku penyimpangan yang dilakukan oleh masnyarakat tidak terlepas dari perlunya tuntutan dalam mengimplementasikan sistem hukum.

Peneliti berpendapat bahwa sistem hukum adalah suatu bagian yang terdiri dari peraturan perundang- undangan, penegak hukum dan masnyarakat. Ketiga bagian dari sistem tersebut harus sejalan dalam memberantas kejahatan yang ada di negeri ini. Peneliti melihat keadaan sosial masnyarakat di indonesia banyaknya pelanggaran hukum dikarena sistem hukum tidak berjalan dengan baik, peraturan yang sudah ada akan tetapi tidak dijalankan dengan baik oleh penegak hukum itu sendiri serta masih acuhnya sikap

\footnotetext{
${ }^{6}$ Bambang Poernomo, 1990, Orientasi Hukum Acara Pidana Indonesia, Yogyakarta: Amarta Buku, Halaman 4
}

masnyarakat dalam keadaan tersebut sehingga pelaksanaan penegakan hukum di negeri ini tidak dapat menjalankan fungsinya sesuai dengan kewajiban yang sudah ditentukan dalam undang-undang.

Indonesia tidak pernah bebas dari peredaran gelap narkotika, kejahatan narkotika merupakan kejahatan sangat luar biasa hal ini disebabkan dikarenakan pelakunya baik pengedar dan penggunanya sama-sama melanggar peraturan perundang-undangan sebagaimana diatur dalam Undang-undang nomor 35 tahun 2009 tentang Narkotika.Ironisnya sekarang pengguna narkotika sudah sampai pada generasi muda yaitu pada pelajar hal ini terjadi pada Tahun 2017 telah ditemukan siswa di Kabupaten Labuhan batu Utara mengkonsumsi narkotika golongan I yaitu ganja. Siswa mengkonsumsi narkotika karena penasaran terhadap rasa ganja sehingga mengikuti ajakan teman untuk mengkonsumsinya. ${ }^{7}$ Perilaku sebagian remaja yang secara nyata telah jauh mengabaikan nilainilai kaidah dan norma serta hukum yang berlaku di tengah kehidupan masyarakat menjadi salah satu penyebab maraknya penggunaan narkoba di kalangan generasi muda. Dalam kehidupan sehari-hari di tengahtengah masyarakat masih banyak dijumpai remaja yang masih melakukan penyalahgunaan narkotika. Berkaitan dengan hal tersebut peneliti memfokusnya kajian terhadap dibentukan gendre narkotika di SMA Negeri 1 Kualuh Selatan kabupaten Labuhanbatu Utara, sebagai upaya generasi muda untuk turut serta

${ }^{7}$ Indra dkk, Implementasi Kebijakan Harm Reduction untuk Meningkatkan Moral Knowing tentang Narkotika pada Siswa SMA di Kabupaten Labuhanbatu Utara, Sumatera Utara Jurnal Pengabdian Pada Masyarakat. Vol. 5, No. 1, 2020, Halaman 19 
Media Komunikasi dan Informasi Hukum dan Masyarakat

membantu pemerintah dalam program indonesia bebas dari narkotika.

\section{B. Rumusan Masalah}

1. Apa Landasan hukum dibentukanya genre narkotika dalam mencegah peredaran gelap narkotika di labuhanbatu utara?

2. Bagaimana cara siswa SMU Negeri 1 kualauh selatan dalam melakukan pencegahan pemberantasan penyalahgunaan dan peredaran gelap narkotika ( P4GN) di Labuhanbatu Utara?

\section{METODE PENELITIAN}

Penelitian ini bersifat deskriptif karena penelitian ini semata-mata menggambarkan suatu objek untuk menggambil kesimpulankesimpulan yang berlaku secara umum ${ }^{8}$. Dalam penelitian ini penulis akan mendekripsikan penelitian ini berkaitan dengan Peran gendre narkotika di SMU Negeri 1 Kualuh Selatan dalam Pencegahan Pemberantasan Penyalahgunaan Dan Peredaran Gelap Narkotika (P4GN) di Kabupaten Labuhanbatu Utara. Penelitian ini dengan menggunakan Metode penelitian hukum Normatif - Empiris. Metode ini pada dasarnya ialah penggabungan antara pendekatan hukum normatif dengan adanya penambahan dari berbagai unsur-unsur empiris. Metode penelitian normatif-empiris ini juga menganalisa tentang implementasi ketentuan hukum normatif Undang-undang Nomor 35 Tahun 2009 Tentang Narkotika, dalam aksinya disetiap peristiwa hukum tertentu yang terjadi dalam suatu masyarakat terkait peredaran gelap narkotika di kabupaten labuhanbatu utara. Dalam penelitian hukum

\footnotetext{
${ }^{8}$ Sutrisno Hadi, Metodologi Research I, (Yogyakarta : Yayasan Penerbitan Fak. Psikologi UGM, 1986), Halaman 3
}

normatif-empiris ini peneliti memfokuskan dengan memakai Pendekatan live case study yaitu pendekatan pada suatu peristiwa hukum yang terjadi di kalangan kaum pelajar terkait penyalahgunaan narkotika.

\section{PEMBAHASAN}

Pelajar SMA Negeri 1 Kualuh Selatan adalah sekolah yang berada di kabupaten labuhanbatu utara tepatnya dikecamatan kulauh selatan. Sekolah ini berkeinginan kuat untuk turut serta membantu pemerintah dalam hal penegakan hukum tentang pencegahan pemberantasan penyalahgunaan dan peredaran gelap narkotika (P4GN). Dasar dibentukanya Gendre Narkotika dikalangan pelajar yaitu berdasarkan Undang-undang nomor 35 tahun 2009 tentang Narkotika. Terkait peran serta masnyarakat dalam mencegah peredaran narkotika tertuang dalam BAB XIII Pasal 104 Masyarakat mempunyai kesempatan yang seluas-luasnya untuk berperan serta membantu pencegahan dan pemberantasan penyalahgunaan dan peredaran gelap Narkotika dan Prekursor Narkotika.Selanjutnya Intruksi Presiden nomor 6 tahun 2008 tentang Rencana Aksi Nasional Pencegahan dan pemberantasan penyalahgunaan dan peredaran gelap narkotika dan prekursur narkotika. Selanjutnya Peraturan Bupati Labuhanbatu Utara Nomor 14 Tahun 2017 Tentang Satuan Tugas Pemberantasan, Pencegahan Penyalahgunaan Dan Peredaran Gelap Narkotika Di Kabupaten Labuhanbatu Utara.

Narkotika adalah Zat/obat yg berasal dari tanaman atau bukan tanaman (sintetis maupun semi sintetis) yang menyebabkan penurunan/perobahan kesadaran, hilangnya rasa dan juga rasa sakit serta dapat menimbulkan ketergantungan, dan Psikotropika 
Media Komunikasi dan Informasi Hukum dan Masyarakat

Yaitu Zat/obat baik alamiah maupun sintetis (bukan narkotika), yang mempengaruhi syaraf pusat menyebabkan perobahan pada aktivitas mental dan perilaku. Sedangkan Zat adiktif yaitu Yang berasal dari tanaman atau bukan tanaman (sentetis maupun semi sintetis) yang menyebabkan ketergantungan dan menurunkan susunan syaraf pusat, namun dalam penyalahgunaan narkotika bisa mengakibatkan ketergantungan dan melanggar peraturan perundang-undangan karena sifatnya ilegal.

Melalui progarm GenRe Narkotika, SMA Negeri ini Kualuh Selatan ini ingin membangun kesadaran kaum muda betapa berbahaya narkoba sehingga tak mudah terbujuk rayuan bandar narkoba yang mengintai di luar dari lingkungan masnyarakat. Penggunaan narkoba banyak dilakukan oleh remaja atau kelompok usia muda. Hal ini tidak terlepas dari sifat remaja yang mempunyai rasa ingin tahu yang lebih besar. ${ }^{9}$

GenRe Narkotika ini dibentuk di sekolah dengan tujuannya yaitu untuk membantu pemerintah dalam program pencegahan pemberantasan penyalahgunaan dan peredaran gelap narkotika (P4GN) terkhusus di kabupaten Labuhanbatu Utara. Program GenRe ini dilaksanakan dengan cara mensosialisasikan dilingkungan sekolah bahwa dengan mengunakan Narkotika bisa menghancurkan masa depan bangsa, namun peneliti melihat masih kurang efektifnya program ini dikarenakan kurang dukungan dari pemerintah kabupaten labuhanbatu utara, dikarenakan GenRe ini tidak disosialisasikan kepada sekolah-sekolah yang ada di Kabupaten labuhanbatu utara. lebih lanjut menurut peneliti peredaran narkotika sudah pada generasi muda, Karena pemuda sebagai generasi yang

\footnotetext{
${ }^{9}$ Sri purwatiningsih, penyalahgunaan narkoba di indonesia.jurnal kependudukan dan kebijakan Halaman 43
}

diharapkan menjadi penerus bangsa, semakin hari semakin rapuh digerogoti zat-zat adiktif penghancur syaraf sehingga pemuda tersebut tidak dapat berpikir jernih, Akibatnya, generasi harapan bangsa yang tangguh dan cerdas hanya akan tinggal kenangan.Sasaran dari penyebaran narkoba ini adalah kaum muda atau remaja. Usia sasaran Narkotika ini adalah usia pelajar, yaitu berkisar umur 11 sampai 18 tahun.

\section{Maraknya Peredaran Narkotika} dilabuhanbatu utara sangat mempengaruhi moral masnyarakat terkhusus generasi muda dikarenakan dapat menimbulkan ketergantungan (adiksi) fisik dan psikologis Penyalahgunaan narkotika dan obat-obatan terlarang di kalangan generasi muda dewasa ini kian meningkat Maraknya penyimpangan perilaku generasi muda tersebut, dapat membahayakan keberlangsungan hidup bangsa ini di kemudian hari. Katakan Tidak Pada Narkoba adalah sebuah niat, ucapan dan tindakan yang wajib dilakukan untuk memerangi penyalahgunaan Narkoba, bukan hanya hanya sebatas tertulis dan terucap saja tanpa aplikasi, akan tapi perlu adanya sebuah tindakan nyata yang harus dilakukan oleh generasi muda ini.

Pemerintah Kabupaten Labuhanbatu Utara melalui Badan Kesatuan Bangsa dan Politik (Kesbangpol) menggelar sosialisasi Pencegahan Pemberantasan Penyalahgunaan dan Peredaran Gelap Narkotika (P4GN).Acara sosialisasi P4GN itu digelar pada hari Selasa (8/10) di Aula Ahmad Dewi Syukur, H. Endar Sakti, Hasibuan mewakili Bupati Labura $\mathrm{H}$. Kharuddin Syah, SE membuka sosialisasi P4GN sekaligus membacakan pidato tertulis Bupati. ${ }^{10}$ Berdasarkan hal tersebut peneliti berpendapat

\footnotetext{
${ }^{10} \mathrm{https}$ ://labura.go.id/pemkab-labura-gelarsosialisasi-p4gn/diakses pada tanggal 5 Mei 2020
} 
Media Komunikasi dan Informasi Hukum dan Masyarakat

kegiatan yang dilakukan oleh pemerintah daerah hanya sebatas serimonial saja seharusnya pemerintah lebih aktif lagi mensosialisakan ke dunia pendidikan terkhusus kesekolah-sekolah dan bekerja sama dengan pihak yang punya kopetensi dibidangnya seperti dari bidang kesehatan serta dibidang penegak hukum. Penyelesaian permasalahan narkotika harus diselesaikan dengan sistem yang baik yaitu mulai dari unsur pemerintahan, penegakan hukum sampai pada masnyarakat yang sangat berperan penting dalam pemberantasan dan pencegahan peredaran narkotika sebagaimana amanah dari undang- undang nomor 35 tahun 2009 tentang narkotika yang tertuang dalam pasal 105 yang menyatakan bahwa Masyarakat mempunyai hak dan tanggung jawab dalam upaya pencegahan dan pemberantasan penyalahgunaan dan peredaran gelap narkotika dan Prekursor Narkotika.

Program GenRe adalah program yang mengedepankan pembentukan karakter bangsa dikalangan generasi muda. Program GenRe merupakan wadah untuk mengembangkan karakter bangsa karena mengajarkan remaja untuk menjauhi NAPZA (Narkotika, Psikotropika, dan Zat Adiktif) guna menjadi remaja tangguh dan dapat berkontribusi dalam pembangunan serta berguna bagi nusa dan bangsa. Keberadaan duta Genre sekaligus menekan maraknya permasalahan remaja, dan yang paling menonjol adalah permasalahan seputar penyalahgunaan narkoba dan rendahnya pengetahuan tentang kesehatan bagi pengguna dan kurang pahamnya akan sanksi hukum bagi pelaku pengedar dan pemakai narkotika yang relatif masih rendah serta masih banyaknya menimpa remaja, sehingga peran duta Genre perlu terus digiatkan dalam hal melakukan sosialisasi kesekolah-sekolah dan melibatkan pihak yang punya peran penting dalam program P4GN terkhusus untuk wilayah kabupaten Labuhanbatu Utara.

\section{Pentingnya Mensosialisasikan Peran GenRe Narkotika dalam pola hidup siswa}

Tindakan preventif adalah tindakan yang dilakukan untuk mencegah atau menjaga kemungkinan yang akan terjadi dalam kejahatan. ${ }^{11}$ Siswa perlu mengampanyekan kepada remaja agar mempunyai target pendidikan dan keterampilan hidup agar kelak mempunyai keberanian untuk menghadapi dan mengatasi masalah dan kesulitan dalam hidup sehari-hari. Perlunya keterampilan hidup bagi remaja yaitu:

1. Membantu remaja mencapai tugas dan perkembangan pribadi, antara lain pertumbuhan fisik, perkembangan mental, perkembangan emocional, dan perkembangan spiritual.

2. Membantu remaja mncapai tugas pertumbuhan dan perkembangan sosial, antara lain melanjutkan sekolah, mencari pekerjaan, memuli kehidupan berkeluarga, menjadi anggota masyarakat dan mempraktekkan hidup sehat.

Program GenRe yang dikampanyekan kesekolah-sekolah yang ada dilabuhanbatu utara bertujuan untuk memfasilitasi remaja agar belajar memahami dan mempraktikkan perilaku hidup sehat dan berakhlak untuk mencapai ketahanan, serta agar remaja memahami dan mempraktekkan pola hidup sehat dan berakhlak, pola hidup yang berketahanan

\footnotetext{
${ }^{11}$ Indra dkk, Implementasi kebijakan harm reduction,Deepublish publiser. Yogyakarta 2019, Halaman54
} 
Media Komunikasi dan Informasi Hukum dan Masyarakat

sehingga dapat mempersiapkan diri menjadi generasi yang cerdas dan kuat.

GenRe punya peranan penting dalam mengedukasi rekan sebaya, untuk menghindari sejumlah permasalahan sosial seperti bahaya Narkoba di kalangan generasi muda. peneliti berharap GenRe Narkotika ini tak hanya mengedukasi siswa, namun juga mampu menjadi agen perubahan di tengah-tengah masyarakat, terutama tempat tinggal masingmasing, dalam mensosialisasikan bahaya Narkoba. Dalam mengantisipasi serangan narkotika dilabuhanbatu utara, berbagai upaya harus di lakukan baik itu lewat sosialisasi di lingkungan sekolah-sekolah maupun dilingkungan masyarakat. Perlunya dorongan dari pemerintah daerah untuk membantu keterbatasan anggaran yang ada disekolah dalam mensosialisasikan GenRe Narkotika di lingkungan sekolah diseluruh wilayah kabupaten labuhanbatu utara. peneliti berharap, masyarakat terpanggil untuk ikut berperan dalam mengantisipasi bahaya Narkoba minimal di lingkungan Keluarga dan terus giat untuk menyadarkan masyarakat tentang bahaya Narkotika.

Promosi GenRe Narkotika ini digencarkan untuk mengajak para remaja berperilaku sehat dan berakhlak, mengatakan tidak pada narkotika, dan tidak menjadi korban, sehingga remaja ini kedepannya dapat merencanakan kehidupan dan masa depan yang lebih baik dalam membangun kemajuan bangsa dan negara kesatuan republik indonesia.

\section{PENUTUP}

\section{A. Kesimpulan}

Kehidupan remaja yang rentan terhadap NAPZA, untuk itu perlu disikapi dengan memberikan edukasi yang lebih tentang kesehatan dan adanya sanksi hukum bagi pengguna dan pelaku pengedar narkotika berdasarkan Undang-undang nomor 35 tahun 2009 tentang narkotika, serta mempersiapkan masa depan merka yang baik.

Peran GenRe Narkotika Dalam hal ini konselor sebaya sangat penting, karena dianggap lebih dapat diterima oleh jiwa remaja. Dalam hal siswa berpengaruh untuk mengampanyekan program GenRe Narkotika dengan melakukan beberapa langkah yang ditempuh untuk mewujudkan tujuan dikembangkannya program Genre yang telah dibentuk oleh SMA Negeri 1 Kualuh Selatan Kabupaten Labuhanbatun Utara dan kedepan terkhusus pemerintah Kabupaten Labuhanbatu Utara menyiapkan para remaja dalam hal jenjang pendidikan yang terencana sebagai upaya peran pendidikan untuk membentuk karakter siswa tersebut sebagai capaian akhir dalam Berkarir dalam pekerjaan yang terencana.

\section{B. Saran}

Bagi Pemerintah Terkhusus Pemerinta Kabupaten Labuhanbatu Utara harus benarbenar konsiten dalam program P4GN dengan mengimplementasikan dengan sistem yaitu mulai dari melibatkan penegak hukum, intansi yang mempunyai peran penting seperti BNNK Labuhanbatu Utara dan melibatkan masnyarakat serta GenRe Narkotika yang sudah dibentuk oleh SMA Negeri 1 Kualuh Selatan Kabupaten Labuhanbatun Utara. 
Media Komunikasi dan Informasi Hukum dan Masyarakat

\section{DAFTAR BACAAN}

Indra dkk, 2019. Implementasi kebijakan harm reduction,Deepublish Publiser. Yogyakarta

Sutrisno Hadi, 1986, Metodologi Research I, Yogyakarta: Yayasan Penerbitan Fak. Psikologi UGM..

Poernomo Bambang., 1990, Orientasi Hukum Acara Pidana Indonesia, Amarta Buku, Yogyakarta.

Indra dkk, 2020 Implementasi Kebijakan Harm Reduction untuk Meningkatkan Moral Knowing tentang Narkotika pada Siswa SMA di Kabupaten Labuhanbatu Utara, Sumatera Utara Jurnal Pengabdian Pada Masyarakat. Vol. 5, No. 1

https://labura.go.id/pemkab-labura-gelarsosialisasi-p4gn/diakses pada tanggal 5 Mei 2020

purwatiningsih Sri, 2001. Penyalahgunaan Narkoba dilindonesia. Populasi jurnal kependudukan dan kebijakan. Universitas Gadjah Mada. Vol. 12 No. 1 